\title{
THE USE OF SLOW-RELEASE FERTILIZERS AS A PART OF OPTIMIZATION OF CELERIAC PRODUCTION TECHNOLOGY
}

\author{
Marcin Niemiec ${ }^{\mathrm{a}^{*}}$, Monika Komorowska ${ }^{\mathrm{b}}$ \\ ${ }^{a}$ Department of Agricultural and Environmental Chemistry, University of Agriculture in Krakow \\ ${ }^{\mathrm{b}}$ Department of Vegetable and Medicinal Plants, University of Agriculture in Krakow \\ "Corresponding author: e-mail: marcin1niemiec@gmail.com
}

\begin{tabular}{|c|c|}
\hline ARTICLE INFO & ABSTRACT \\
\hline $\begin{array}{l}\text { Article history: } \\
\text { Received: March } 2018 \\
\text { Received in the revised form: } \\
\text { April } 2018 \\
\text { Accepted: May } 2018 \\
\end{array}$ & \multirow{2}{*}{$\begin{array}{l}\text { The aim of this study was to assess the possibility of using slow- } \\
\text { release fertilizers under intensive vegetable cultivation. To achieve the } \\
\text { set research objective, a field experiment was set up in } 2017 \text {, where } \\
\text { slow-release fertilizer (NPK (\%) } 20-10-10+4 \mathrm{MgO} \text { ) was applied. The } \\
\text { experiment comprised three levels of fertilization with the use of } \\
\text { slow-release fertilizers, the control without fertilization, and the } \\
\text { control fertilized with conventional fertilizers. The slow-release } \\
\text { fertilizer was applied directly under each plant and in rows - approxi- } \\
\text { mately } 8 \mathrm{~cm} \text { below the root level. The designed systems were evaluat- } \\
\text { ed based on the size of commercial yield, productivity index, agro- } \\
\text { nomic efficiency index, removal efficiency index, and physiological } \\
\text { efficiency index. The results obtained in the field experiment indicate } \\
\text { that the highest plant yield ( } 54.22 \text { Mg of commercial yield·ha }{ }^{-1} \text { ) was } \\
\text { obtained at the highest dose of slow-release fertilizers ( } 600 \mathrm{~kg} \cdot \mathrm{ha}{ }^{-1} \\
\text { applied in rows approximately } 8 \mathrm{~cm} \text { below the root level). In the case } \\
\text { of direct fertilization, in the treatment with the highest dose of slow- } \\
\text { release fertilizer, a reduction in yield was observed. The best results, } \\
\text { in terms of equalizing the mass of individual roots, were obtained } \\
\text { under conventional fertilization. The most favorable value of the } \\
\text { productivity index was obtained in the variant where } 400 \mathrm{~kg} \cdot \mathrm{ha}{ }^{-1} \text { slow- } \\
\text { release fertilizer was applied directly, while in the case of row applica- } \\
\text { tion the best results were obtained at the dose of } 600 \mathrm{~kg} \cdot \text { ha }{ }^{-1} \text {. Celeriac } \\
\text { fertilization with slow-release fertilizers under root may result in } \\
\text { producing a yield of bigger differences in root mass, compared to } \\
\text { conventional fertilization system. }\end{array}$} \\
\hline $\begin{array}{l}\text { Key words: } \\
\text { celeriac, } \\
\text { integrated production, } \\
\text { slow-release fertilizers, } \\
\text { fertilization efficiency }\end{array}$ & \\
\hline
\end{tabular}

\section{Introduction}

Efficiency of agricultural production is one of more important factors that shape the level of human impact associated with this human activity. The use of non-renewable energy resources, emission of biogens and greenhouse gases into the environment as well as emission of toxic trace elements and organic compounds that are active substances of pesticides are regarded as the most important factors associated with the negative impact of agriculture on the environment. Moreover, agricultural activity, particularly in intensive cultivation systems, leads to soil degradation, changes in landscape, and to reduction in 
Marcin Niemiec, Monika Komorowska

biodiversity, both in agroecosystems and in nearby habitats (Forleo et al., 2018). Due to the growing demand for food and raw materials for production of renewable energy carriers, crop cultivation covers more and more land, very often with unfavorable farming conditions. This often translates into a decrease in economic efficiency and environmental efficiency. That is why creating tools for the assessment of efficiency of agricultural systems, and also optimization of production methods in order to minimize the impact on the environment, are strategic roles of science (Brito de Figueirêdo et al., 2016). Actions connected with reduction of the negative impact of agriculture on the environment are a part of all quality management systems (both national and private) in primary production such as Integrated Production, GLOBAL G.A.P., SAI. The quality of obtained products is no less important than the aspect of crop production rationalization. Excessive or improper fertilization as well as using chemical pesticides result in producing products with the increased content of nitrates, pesticide residues. Economic and social development involves an increase in demand for products characterized with proper sensory and qualitative values. Development of quality management systems in agriculture is a step towards meeting the needs of consumers who more and more often look for safe products containing small amounts of substances that are harmful to health, produced respecting natural environmental resources (Alluvione et al., 2011). Crop fertilization is the main factor generating the costs of agricultural production and influencing the quantity and quality of yields. Elements not used by plants are dispersed in the environment. Therefore, optimization of fertilization is a strategic area for development of agriculture and shaping its image in the present-day world (Nardi et al., 2017; Chen et al., 2018b). Efficiency of agricultural production is conditioned by many factors, which include habitat, climatic, and agrotechnical conditions. The effect of optimization of crop fertilization is production of high quality food in terms of chemical composition and technological parameters. Various methods are used in the agricultural practice. Their effect is a decreased use of fertilizer components introduced into agroecosystems. The most common of these methods include increasing the amount of fertilization, using foliar fertilizers, fertilization through fertigation. Trying to meet the needs of developing agriculture, the fertilizer industry introduces a wider and wider assortment of fertilizers that are characterized by a slower release of nutrients, thanks to which, their supply is spread over plant vegetation. Using slow-release fertilizers is a method of fertilization optimization the importance of which has been increasing in the recent years (Gaetano et al., 2016; Nardi et al., 2017; Chen et al., 2018). In these fertilizers, coatings made of various compounds of natural, synthetic or biological origin are a barrier limiting the transfer of fertilizer components to the soil solution (Li et al., 2017). Slow-release fertilizers are used in order to reduce the total amount of plant nutrients introduced into the environment and to limit the energy consumption for fertilization. However, their improper use may bring negative effects in the form of reduced plant yielding (Niemiec, 2014; Niemiec et al., 2015a). Effective use of slow-release fertilizers requires in-depth knowledge about physiological aspects of nutrient uptake in certain habitat and climatic conditions. That is why it is crucial to elaborate the technology of their use. The risk of weak production effects is one of the main causes of the low interest of producers in the use of slowrelease fertilizers.

The aim of the conducted research was to determine the usefulness of using slowrelease fertilizers in celeriac fertilization using two fertilization methods. Fertilization efficiency was evaluated based on the following fertilization efficiency indices: productivity 
The use of slow-release...

index, agronomic efficiency index, removal efficiency index, and physiological efficiency index (IFA, 2007). Indices that reflect fertilization efficiency provide a lot of information about environmental and production-related aspects of nitrogen fertilization.

\section{Material and methods}

To achieve the set objective, two field experiments that differed in the method of application of slow-release fertilizer were conducted. The slow-release fertilizer was applied directly and in rows, approximately $8 \mathrm{~cm}$ below plant roots. Results of earlier studies indicate that using the slow-release fertilizers directly under the root limited the plant growth and had a negative effect on production efficiency indices (Niemiec et al., 2015a; Niemiec et al., 2015b). The experiment was set up on soil with the granulometric composition of medium loam. The forecrop for the studied plants was Chinese cabbage for autumn harvest. Mineral fertilizers in full dose (which is characteristic for intensive cultivations) were used in the cabbage cultivation, with no quality management system. Celeriac (Apium graveolens var. rapaceum) of Diamant F1 cultivar was the test plant. The experiment was set up on 13 May 2017. The plants were harvested on 26 October 2017. The plants were cultivated at $50 \times 30 \mathrm{~cm}$ spacing, from seedlings prepared in multi-cell trays (VEFI system). The density was $65000 \mathrm{pcs} \cdot \mathrm{ha}^{-1}$. Varied fertilization and the manner of fertilizer application were the factors of the experiment. Cultivation and protection of the plants were carried out based on general assumptions of integrated production. Nutrient demand and fertilizer requirements were determined based on the balance method. The experiment was set up using the randomized blocks method in four replications. The plants were irrigated up to the optimum moisture content in order to eliminate the impact of water stress on the result of the experiments. Prior to setting up the experiment, analyses of physicochemical and chemical properties of the soil (Table 2) had been conducted. A slow-release (5-6 months) fertilizer (with NPK composition (\%) of $20-10-10+4 \mathrm{MgO}$ ) was used in the experiment. The experiment comprised three levels of fertilization with the use of slow-release fertilizers, the control without fertilization and the control fertilized with traditional fertilizers in the amount corresponding to plant demand for nutrients, assuming the yield would be at the level of $60 \mathrm{Mg} \cdot \mathrm{ha}^{-1}$ of the commercial yield. The size of the assumed yield was estimated based on the analysis of the productive potential of the habitat and on the history of the field. Conventional phosphorus and potassium fertilizers were applied in their entirety prior to planting, whereas ammonium nitrate was divided into two doses: $60 \%$ of the dose was applied prior to planting and $40 \%$ after planting. The date for topdressing was selected based on the observations of meteorological conditions and monitoring of the condition of the plants. The experimental design is presented in Table 2.

For each fertilization variant, documentation of production and technological processes was kept and it was compliant with guidelines set forth in the Regulation (Regulation, 2013). In accordance with recommendations included in the methodology of integrated protection of celery, the optimal content of nitrogen, potassium and phosphorus of in soil on which the experiment was conducted (taking into account the specific gravity) is $40-80$ $\mathrm{mg} \mathrm{N} \cdot \mathrm{kg}^{-1} ; 40-50 \mathrm{mg} \mathrm{P} \cdot \mathrm{kg}^{-1} ; 110-130 \mathrm{mg} \mathrm{K} \cdot \mathrm{kg}^{-1}$. The obtained results indicate that it contains over three times more chemical elements. On soils used for intensive vegetable cultivation, it is common to observe a high content of fertilizer elements in soil (Bellarby et al., 
Marcin Niemiec, Monika Komorowska

2018). In consequence, according to the principles of rational fertilization, fertilization should be limited or, in some cases, abandoned. However, as stated by Agneessens et al., (2015) and Mariano et al., (2017), in such cases, despite a considerable content of available forms of elements in soil, their deficiencies at the reduced fertilization can be observed. After plant harvest, the amount of yield and its chemical composition were estimated. Based on the obtained data, fertilization efficiency indices were calculated, allowing evaluation of the designed systems. The evaluation was carried out based on the size of the commercial yield, productivity index, agronomic efficiency index, removal efficiency index, and physiological efficiency index.

Table 1.

Selected properties of the soil on which the experiment was conducted

\begin{tabular}{ccccccccc}
\hline \multirow{2}{*}{$\mathrm{pH}$ in $\mathrm{H}_{2} \mathrm{O}$} & \multirow{2}{*}{$\mathrm{pH}$ in $\mathrm{KCl}$} & \multicolumn{2}{c}{$(\%)$} & \multicolumn{3}{c}{$\left(\mathrm{mg} \cdot \mathrm{kg}^{-1}\right)$} \\
\cline { 3 - 9 } & & Total N & Organic C & Mineral N & $\mathrm{P}$ & $\mathrm{K}$ & $\mathrm{Mg}$ & $\mathrm{Ca}$ \\
\hline 6.62 & 6.12 & 0.248 & 2.26 & 272 & 127.2 & 378.3 & 128.1 & 696.3 \\
\hline
\end{tabular}

Table 2.

Experimental design

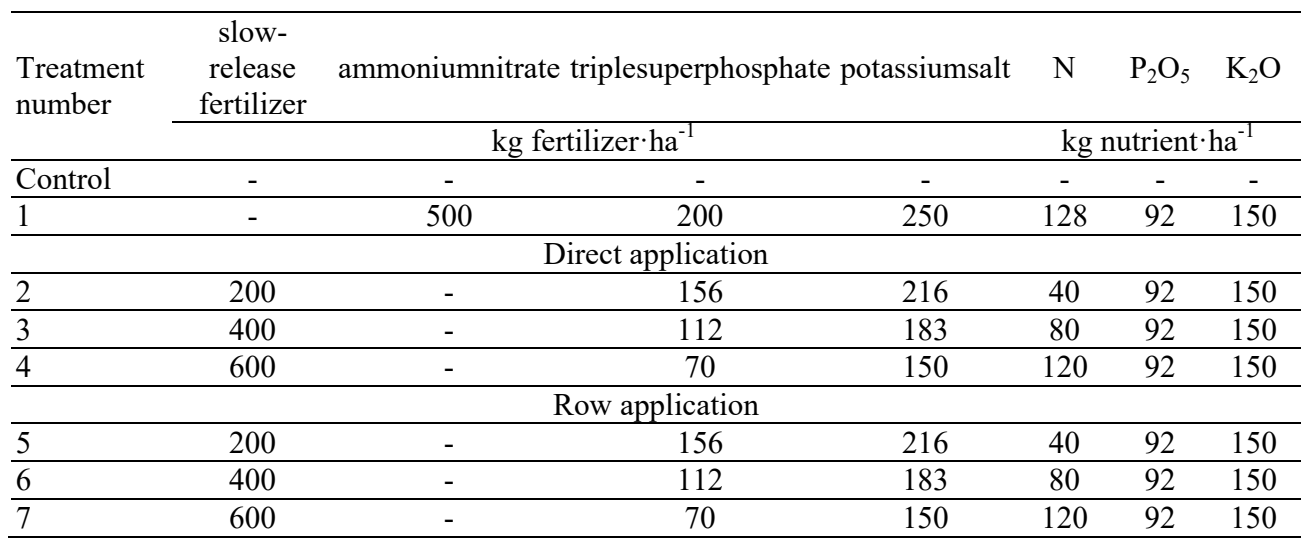

Efficiency coefficients were calculated according to the formulas:

- Productivity index

$$
\mathrm{IE}=\mathrm{Y} / \mathrm{U}
$$

- agronomic efficiency index:

$$
\mathrm{AE}=(\mathrm{Y}-\mathrm{Yo}) / \mathrm{F}
$$

- removal efficiency index:

$$
\mathrm{PFP}=\mathrm{Y} / \mathrm{F}
$$

- Physiological efficiency index. 
The use of slow-release...

$$
\begin{aligned}
& \mathrm{PE}=(\mathrm{Y}-\mathrm{Yo}) /(\mathrm{U}-\mathrm{Uo}) \\
& \mathrm{Y} \quad-\text { nutrient content in the crop, }\left(\mathrm{kg} \cdot \mathrm{ha}^{-1}\right) \\
& \mathrm{Y}_{0} \quad-\text { nutrient content in the crop from the control object, }\left(\mathrm{kg} \cdot \mathrm{ha}^{-1}\right) \\
& \left.\mathrm{U}-\text { amount of uptake of the nutrient with crop, }(\mathrm{kg} \cdot \mathrm{ha})^{-1}\right) \\
& \mathrm{U}_{0} \quad-\text { amount of uptake of the nutrient with crop from the control object, }\left(\mathrm{kg} \cdot \mathrm{ha}^{-1}\right) \\
& \mathrm{F} \quad-\text { the dose of nutrient, }\left(\mathrm{kg} \cdot \mathrm{ha}^{-1}\right)
\end{aligned}
$$

\section{Results and discussion}

Thanks to using slow-release fertilizers, in certain soil and climatic conditions production efficiency can be increased and dispersion of biogens in the environment can be reduced, which has been highlighted by numerous authors (Shan et al., 2015; Li et al., 2017). As a rule, slow-release fertilizers are characterized by a slower release of nutrients, which should allow for their application near the plant root zone. They can contain fertilizer components enclosed in granules with various solubility. It is increasingly common to use nanoparticles of various elements for fertilizer production (Liu and Lal, 2015). From the economic point of view, the most important parameters in the assessment of agricultural systems are the amount of yield and its technological parameters, the most important of which is unit mass of product. The purpose of production is to produce a substantial yield varying in unit mass. To achieve the set research objective, the experiment was carried out on soil rich in fertilizer elements with a good structure characterized by an optimal reaction for celeriac production. In such conditions, the yield obtained in the control treatment was

\begin{tabular}{|c|c|c|c|c|c|c|c|c|}
\hline 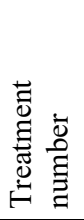 & $\begin{array}{l}\frac{\sigma}{0} \\
\frac{0}{2} \\
0 \\
00 \\
\frac{\pi}{0} \\
⿱ 亠 乂 \\
\sum\end{array}$ & $\begin{array}{l}\mathbb{\infty} \\
\stackrel{\mathbb{\pi}}{\simeq} \\
\tilde{\simeq}\end{array}$ & 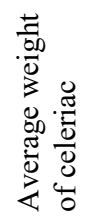 & $\begin{array}{l}\stackrel{0}{\infty} \\
\tilde{\Xi} \\
\approx\end{array}$ & 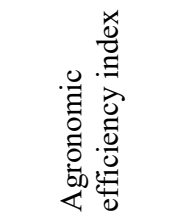 & 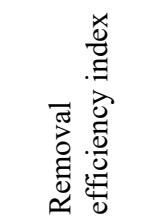 & 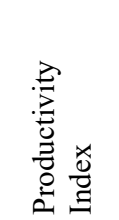 & 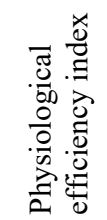 \\
\hline Unit & \multicolumn{2}{|c|}{$\mathrm{Mg} \cdot \mathrm{ha}^{-1}$} & \multicolumn{2}{|c|}{$g \cdot u^{-1} t^{-1}$} & $\begin{array}{l}\mathrm{kg} \mathrm{DM} \cdot \mathrm{kg} \mathrm{N} \\
\text { applied }^{-1}\end{array}$ & $\begin{array}{l}\mathrm{kg} \mathrm{N} \cdot \mathrm{kg} \mathrm{N} \\
\text { applied }^{-1}\end{array}$ & \multicolumn{2}{|c|}{$\mathrm{kg} \mathrm{DM} \cdot \mathrm{kg} \mathrm{N}^{-1}$} \\
\hline $\mathrm{C}^{*}$ & $29.25 \mathrm{a}$ & $26.23-34.25$ & 531.9 & $476-588$ & - & - & - & - \\
\hline 1 & 48.79 & $46.56-54.56$ & 887.1 & $824-915$ & $23.51 \mathrm{a}$ & $0.759 b$ & $58.69 \mathrm{a}$ & $16.61 \mathrm{~b}$ \\
\hline 2 & $42.03 b$ & $40.05-45.89$ & 764.2 & $702-796$ & $48.89 \mathrm{c}$ & $0.826 \mathrm{~b}$ & $160.8 \mathrm{c}$ & $16.71 \mathrm{~b}$ \\
\hline 3 & $47.33 \mathrm{c}$ & $44.58-50.58$ & 860.5 & $728-942$ & $33.47 \mathrm{~b}$ & $0.817 b$ & $87.64 b$ & $17.93 b$ \\
\hline 4 & $44.57 \mathrm{~b}$ & $38.23-50.62$ & 810.4 & 614-1112 & $18.43 \mathrm{a}$ & $0.597 \mathrm{a}$ & $53.61 \mathrm{a}$ & $14.20 \mathrm{ab}$ \\
\hline 5 & $38.57 \mathrm{~b}$ & $37.58-41.56$ & 701.3 & $647-788$ & $32.89 b$ & $0.568 \mathrm{a}$ & $136.14 \mathrm{c}$ & $12.33 \mathrm{a}$ \\
\hline 6 & $48.96 \mathrm{c}$ & $47.96-50.11$ & 890.1 & $612-988$ & $39.25 \mathrm{c}$ & $1.056 \mathrm{~b}$ & $97.51 \mathrm{~b}$ & $18.64 \mathrm{~b}$ \\
\hline 7 & $54.22 \mathrm{c}$ & $52.68-57.42$ & 985.8 & $752-1258$ & $33.54 \mathrm{~b}$ & $0.946 \mathrm{~b}$ & $72.83 \mathrm{ab}$ & $20.38 b$ \\
\hline
\end{tabular}
at the level of $29.25 \mathrm{Mg} \cdot \mathrm{ha}^{-1}$ (Table 3). In his research, Niemiec (2015a) obtained a similar amount of yield of celeriac. The content of mineral nitrogen and available forms of phosphorus and potassium points to irrational fertilization management in the previous years.

Table 3.

Results of conducted experiment

Different letters indicate statistically significant differences at the significance level $\mathrm{p}=0.05$.

* Control 
A high abundance of soils used intensively for vegetables is indicated in other studies (Niemiec, 2014; Niemiec et al., 2015a; Niemiec et al., 2015b). By applying conventional fertilization resulting from fertilizer needs (calculated using the balance method with taking the soil resources into account), a commercial yield of $48.79 \mathrm{Mg} \cdot \mathrm{ha}^{-1}$ was obtained.

Fertilization with slow-release fertilizers $\left(200 \mathrm{~kg} \cdot \mathrm{ha}^{-1}\right)$, using both the direct method and the row method, caused a statistically significant increase in the commercial yield (Table 3). Further increase of the dose of slow-release fertilizers translated into the size of the generated commercial yield, and at their dose of $600 \mathrm{~kg}$ in the treatments fertilized in rows $54.22 \mathrm{Mg} \cdot \mathrm{ha}^{-1}$ of celeriac roots was collected. In the case of direct fertilization, in the treatment with the highest dose of slow-release fertilizer, a reduction in yield was observed (Table 3). Using fertilizers directly, near the plant root system, may involve an increase in the level of soil solution salinity, which has been emphasised by Niemiec et al. (2015a). One of the most important qualitative properties of celeriac roots, both the ones intended for consumption and for processing, is equalization of the size of individual roots. In terms of this qualitative feature, the best yields were obtained with application of conventional fertilizers. In this variant, the average weight of commercial root was $887 \mathrm{~g}$ (Table 3) and relative difference in individual roots was the lowest. The highest differences in weight of individual roots were observed in the case of the highest dose of slow-release fertilizers, both in the case of direct and row fertilization. The amount of yield and technological quality of the product are insufficient parameters to assess the present-day agriculture. Indices that determine both the production and environmental aspects of crop production must absolutely be used (Verzeaux et al., 2017). The manner of fertilizer application is of great importance for reaching the set production and environmental goals which are always connected with an increase in fertilization efficiency (Mucheru -Muna et al., 2010; Nkebiwe et al., 2016).

The productivity index informs how much has plant yield increased after application of $1 \mathrm{~kg}$ nitrogen in the form of fertilizer. In our study it ranged from 58.69 to $160.8 \mathrm{~kg}$ $\mathrm{DM} \cdot \mathrm{kg} \mathrm{N}^{-1}$. The lowest value of this parameter was found in the conventionally fertilized treatment and with the highest dose of fertilizer applied directly. The highest value of the said factor was observed at the smallest dose of slow-release fertilizers (Table 3). Niemiec et al., (2015a) determined that the values of the celeriac efficiency index in different fertilization variants ranged from 19.35 to $151.76 \mathrm{~kg}$. A high value of the index is not necessarily indicative of good efficiency of production. Its value must always be evaluated in connection with the amount of yield (Dua et al., 2007). The most common values of this parameter in conventional agricultural systems range from 40 to $80 \mathrm{~kg} \cdot \mathrm{kg}^{-1}$ dry matter (IFA 2007). Values above 60 can be found in well managed systems, at the low nitrogen content in soil. In our research, the most favorable value of the productivity index was obtained in the variant where $400 \mathrm{~kg} \cdot \mathrm{ha}^{-1}$ of slow-release fertilizer was applied directly, while in the case of row application, the best results were obtained at the dose of $600 \mathrm{~kg} \cdot \mathrm{ha}^{-1} ; 87.64$ and 97.51 $\mathrm{kg} \cdot \mathrm{kg}^{-1}$, respectively. Amanullah and Almas (2007) report the value of the productivity index in different fertilization variants of wheat within the range from 28 to $55 \mathrm{~kg} \cdot \mathrm{kg}^{-1}$ grain. Szczepaniak et al., (2013) state that under conditions of optimizing maize fertilization with nitrogen, the value of the productivity index can reach the level of more than $60 \mathrm{~kg} \cdot \mathrm{kg}^{-1}$. In the case of other cereals, these authors obtained approximately $20 \%$ lower values of this parameter. Li et al., (2012) observed an increase in the value of the productiv- 
The use of slow-release...

ity index in winter wheat cultivation, from approximately 35 at conventional cultivation to over $85 \mathrm{~kg} \cdot \mathrm{kg}^{-1}$ under row application of nitrogen fertilizers.

The agronomic efficiency index is the most important indicator that reflects the efficiency of agricultural systems. This is because it shows the content of nitrogen, both coming from mineral fertilizers and nitrogen present in soil. When farming on soils rich in nutrient elements, characteristic for vegetable production, it may be the most important indicator of fertilization efficiency (Xu et al., 2017). In our research, the average value of the agronomic efficiency index was $32.58 \mathrm{~kg}$ of the product $\mathrm{kg}^{-1}$ and ranged between 18.43 and $33.54 \mathrm{~kg}$ of the product $\mathrm{kg}^{-1}$ (Table 3). The lowest value of this parameter was observed in the treatments with the highest dose of the slow-release fertilizer (Table 3). Its average value for the directly fertilized treatment was $48.89 \mathrm{~kg}$ of the product $\cdot \mathrm{kg}^{-1} \mathrm{~N}$, whereas in the case of row application the value of this parameter was at the level of $39.25 \mathrm{~kg}$ of the product $\mathrm{kg}^{-1} \mathrm{~N}$ (dry matter). The lowest value of this parameter was recorded in the case of conventional fertilization and in the case of direct application of $600 \mathrm{~kg} \cdot \mathrm{ha}^{-1}$ slow-release fertilizer. The value of the agronomic efficiency index for rice production in the developing countries is approximately $13 \mathrm{~kg}$ of product $\mathrm{kg}^{-1}$ (Xu et al., 2017). Niemiec et al., (2015a) reported the value of this parameter in conventional cultivation of celery to be approximately $20 \mathrm{~kg} \cdot \mathrm{kg}^{-1}$. In the case of combination of fertilization with slow-release fertilizers and conventional ones, the value of this parameter increased to about $90 \mathrm{~kg}$ of the product $\cdot \mathrm{kg}^{-1}$ (dry matter). In our research, we observed that the manner of fertilizer application had a significant effect on the efficiency of fertilization. Ma et al., (2015) drew similar conclusions in the case of maize production. Similarly, Nardi et al., (2018) stated that application of slow-release fertilizers significantly increased the efficiency of agricultural production, both from the environmental and production point of view.

In terms of evaluation of fertilization impact on the environment, removal efficiency is the most important index. Due to the limited possibility of nitrogen absorption in soil, most of its unused resources, both during vegetation and in winter, is dispersed into the environment. High values of this parameter may indicate proper use of nitrogen from fertilizers and soil resources, but may also point to deficient fertilization with this element, which may be unfavorable from the production economics point of view. With a high nitrogen content in soil and with rational fertilization, it is possible to obtain values of this parameter at the level of more than $1 \mathrm{~kg} \mathrm{~N} \mathrm{~kg} \cdot \mathrm{N}^{-1}$ nitrogen applied with fertilizers. The value of the removal index in individual variants of the performed experiment varied from 0.568 to $1.056 \mathrm{~kg} \mathrm{~N}$ $\mathrm{kg} \cdot \mathrm{N}^{-1}$ nitrogen applied with fertilizers. The lowest value of the investigated parameter was observed in the case of the directly fertilized treatment (in the amount of 400 and $600 \mathrm{~kg}$ ) in which the value of the removal index was approximately $0.6 \mathrm{~kg} \mathrm{~N} \mathrm{~kg} \cdot \mathrm{N}^{-1}$ nitrogen applied with fertilizers (Table 3 ). In other cases, there were no statistically significant differences in the value of this parameter. The obtained results, in the conventionally fertilized treatments and with the use of slow-release fertilizers using the row method, were high and characteristic of well-managed agricultural systems. Significantly lower values of the nitrogen removal index were obtained by Shan et al., (2015) in cultivation of Chinese cabbage, and by Wang et al. (2017) in cultivation of agricultural plants.

The physiological efficiency index reflects plant growth conditions that cover the parameters of climate, soil fertility, plant production potential, and also the strategy of fertilization and plant protection policy. Low values of this index suggest occurrence of a stressor which limits plant growth. Based on the value of the physiological efficiency index, it is 
impossible to determine the causes of the problem. Nevertheless, it provides reliable information about efficiency of the agricultural system. The physiological efficiency index ranged in other variants of the experiment between 12.33 and 20.38. Its lowest value was obtained in the case of fertilization with slow-release fertilizers in the amount of $200 \mathrm{~kg} \cdot \mathrm{ha}^{-1}$ applied in rows, and at the dose of $600 \mathrm{~kg}$ applied directly. Environmental conditions in all variants of the experiment were identical. That is why the obtained differences result from the fertilization policy (which has an effect on availability of elements and on properties of soil and soil solution, particularly near the root zone). From the point of view of the parameter being discussed, no statistically significant differences in individual study treatments were detected. Only in the case of direct fertilization were there lower values of this parameter (Table 3).

\section{Conclusions}

Application of slow-release fertilizers using the row method yields better production results compared to spot-application of fertilizer under the root level.

1. The highest commercial yield of celeriac was obtained in the case of application of slow-release fertilizers in rows in the amount of $600 \mathrm{~kg} \cdot \mathrm{ha}^{-1}$.

2. The most favorable value of the productivity index was obtained in the variant where $400 \mathrm{~kg} \cdot \mathrm{ha}^{-1}$ slow-release fertilizer was applied directly, while in the case of row application the best results were obtained at the dose of $600 \mathrm{~kg} \cdot \mathrm{ha}^{-1}$.

3. Celeriac fertilization with slow-release fertilizers under root may result in producing a yield of bigger differences in root mass, compare with conventional fertilization system.

4. In terms of the impact on the environment, the best results were obtained at conventional fertilization and at fertilization with slow-release fertilizers in the row technique.

\section{References}

Agneessens, L., Viaene, J., VandenNest, T., Vandecasteele, B., De Neve, S. (2015). Effect of ensilaged vegetable crop residue amendments on soil carbon and nitrogen dynamics. Scientia Horticulturae, 192(31), 311-319.

Alluvione, F., Moretti, B., Sacco, D., Grignani, C. (2011). EUE (energy use efficiency) of cropping systems for a sustainable agriculture. Energy, 36, 4468-4481.

Amanullah, Almas, L.K. (2009). Partial factor productivity, agronomic efficiency, and economic analyses of maize in wheat-maize cropping system in Pakistan. Selected Paper prepared for presentational the Southern Agricultural Economics Association Annual Meetings, Atlanta, Georgia, January 31- February 3. p. 26.

Brito de Figueirêdo, M.C., Potting, J., LopesSerrano, L.A., Bezerra, M.A., da Silva Barros, V., Sonsol-Gondim, R., Nemecek, T. (2016). Environmental assessment of tropical perennialcrops: the case of the Brazilian cashew. Journal of Cleaner Production, 112(1), 131-140.

Chen, Q., Qin, J., Sun, P., Cheng, Z., Shen, G. (2018a). Cowdung-derived engineered biochar for reclaiming phosphate from aqueous solution and its validation as slow-release fertilizer in soilcrop system. A Journal of Cleaner Production, 17, 2009-2018.

Chen, S., Yang, M., Ba, C., Yu, S., Jiang, Y., Zou, H., Zhang, Y. (2018b). Preparation and characterization of slow-release fertilizer encapsulated by biochar-based water born ecopolymers. Science of The Total Environment, 615(15), 431-437. 
The use of slow-release...

Dua, V.K., Govindakrishnan, P.M., Lal, S.S., Khurana, S.M.P. (2007). Partial factor productivity of nitrogen in potato. Better Crops, 91(4), 26-27.

Forleo, M.B., Palmieri, N., Suardi, A., Coalo, D., Pari, L. (2018). The eco-efficiency of rapeseed and sunflowercultivation in Italy. Joining environmental and economic assessment. Journal of CleanerProduction, 172(20), 3138-3153.

Gaetano, M., Polinori, P., Tei, F., Benincasa, P., Turchetti, L. (2016). An economic analysis of the efficiency and sustainability of fertilization programs at level of operational systems of soft wheat in Umbria. Agriculture and Agricultural Science Procedia, 8, 298-306.

IFA. (2007). Sustainable management of the nitrogen cycle in agriculture and mitigation of reactive nitrogen side effects. International Fertilizer Industry Association. Paris 53.

Li, L-P., Liu, Y-Y., Lou, S-G., Peng, X-L. (2012). Effects of nitrogen management on the yield of winterwheat in coldarea of northeastern China. Journal of Integrative Agriculture, 11(6), 10201025.

Li, Y., Sun, Y., Liao, S., Zou, G., Zhao, T., Chen, Y., Yang, J., Zhang, L. (2017). Effects of two slowrelease nitrogen fertilizers and irrigation on yield, quality, and water-fertilizer productivity of greenhouse tomato. Agricultural Water Management, 186, 139-146.

Liu, R., Lal, R. (2015). Potentials of engineered nano particles as fertilizers for increasing agronomic productions. Science of The Total Environment, 514, 131-139.

Ma, Q., Wang, X., Li, H., Li, H., Zhang, F., Rengel, Z., Shen, J. (2015). Comparing localized application of different $\mathrm{N}$ fertilizer species on maize grain yield and agronomic $\mathrm{N}$-use efficiency on a calcareous soil. Comparing localized application of different $\mathrm{N}$ fertilizer species on maize grain yield and agronomic N-use efficiency on a calcareous soil. Plant Science, 264, 48-56.

Mariano, E., Otto, R., Montezano, Z.F., Cantarella, H., Trivelin, P.C.O. (2017). Soil nitrogen availability indices as predictors of sugar can enitrogen requirements. European Journal of Agronomy, 89, 25-37.

Mucheru-Muna, M., Pypers, P., Mugendi, D., Kung'u, J., Mugwe, J., Merckx, R.,Vanlauwe, B. (2010). A staggered maize-legume intercrop arrangement robustly increases crop yields and economic returns in the highlands of Central Kenya. Field Crop Research Journal, 115, 132-139.

Nardi, P., Neri, U., Di Matteo, G., Trinchera, A., Napoli, R., Farina, R., Subbaravo, G.V., Benedetti, A. (2018). Nitrogen release from slow-release fertilizers in soils with different microbial activity. Pedosphere, In press.

Niemiec, M. (2014). Efficiency of slow-acting fertilizer in the integrated cultivation of chinese cabbage. Ecological Chemistry and Engineering A, 21(3), 333-346.

Niemiec, M., Cupiał, M., Szelag-Sikora, A. (2015a). Evaluation of the Efficiency of Celeriac Fertilization with the Use of Slow-acting Fertilizers. Agriculture and Agricultural Science Procedia, 7 , 177-183.

Niemiec, M., Szeląg-Sikora, A., Cupiał, M. (2015b). Efficiency of celeriacfertilization with phosphorus and potassiumunderconditions of integrated plant production. Agriculture and Agricultural Science Procedia, 7, 184-191.

Nkebiwe, P.M., Weinmann, M., Bar-Tal, A., Müller, T. (2016). Fertilizer placement to improve crop nutrientacquisition and yield: A review and meta-analysis. Field CropsResearchJournal, 196, 389-401.

Regulation of the Minister of Agriculture of 8 April 2013 amending the Regulation on Integrated Production. Journal of Laws 2013 item 452.

Shan, L., He, Y., Chen, J., Huang, Q., Lian, X., Wang, H., Liu, Y. (2015). Nitrogen surface runoff losses from a Chinese cabbage field under different nitrogen treatments in the Taihu Lake Basin, China. Agricultural Water Management, 159, 255-263.

Szczepaniak, W., Barłóg, P., Łukowiak, R., Przygocka-Cyna, K. (2013). Effect of balanced nitrogen fertilization in four-year rotation plant productivity. Journal of Central European Agriculture, 14(1), 64-77. 
Verzeaux, J., Hirel, B., Dubois, F., Leac, P.J., Tétu, T. (2017). Agricultural practices to improve nitrogen use efficiency through the use of arbuscular mycorrhizae: Basic and agronomicaspects. Plant Science, 264, 48-56.

Wang, Z., Heiniger, R.W., Ronald, J., Gehl, R.J., Heitman, A.J., Miguel, S., Castillo, M.S., Smyth, T.J., Carl, R., Crozier, C.R. (2017). Nitrogen fertilization effects on yield and nutrient removal of biomass and sweet sorghum. Agronomy Journal, 109(4), 1-7.

Xu, X., He, P., Yang, F., Ma, J., Pampolino, M.F., Johnston, A.M., Zhou, W. (2017). Methodology of fertilizer recommendation based on yield response and agronomic efficiency for rice in China. Field Crops Research, 206, 33-42.

\title{
WYKORZYSTANIE NAWOZÓW WOLNODZIALAJĄCYCH JAKO ELEMENT OPTYMALIZACJI TECHNOLOGII PRODUKCJI WARZYW
}

\begin{abstract}
Streszczenie. Celem pracy była ocena możliwości wykorzystania nawozów wolnodziałających w warunkach intensywnej uprawy warzyw. W ramach realizacji założonego celu badawczego, w 2017r. założono doświadczenie polowe, w którym zastosowano nawozy o spowolnionym uwalnianiu składników, o składzie NPK (\%) 20-10-10+4MgO. Doświadczenie obejmowało 3 poziomy nawożenia z wykorzystaniem nawozów wolnodziałających, obiekt kontrolny bez nawożenia oraz obiekt kontrolny nawożony nawozami tradycyjnymi. Nawóz wolnodziałający był aplikowany punktowo pod każdą roślinę oraz rzędowo, na głębokości około $8 \mathrm{~cm}$ poniżej poziomu korzeni. Ocenę zaprojektowanych systemów dokonano w oparciu o wielkość plonu handlowego, wskaźnik produktywności, wskaźnik efektywności agronomicznej, wskaźnik efektywności usunięcia oraz wskaźnik efektywności fizjologicznej. Wyniki uzyskane w warunkach doświadczenia polowego wskazują, że największy plon roślin, na poziomie $54,22 \mathrm{Mg}$ plonu handlowego $\mathrm{ha}^{-1}$, uzyskano w warunkach największej dawki nawozów wolnodziałających, na poziomie $600 \mathrm{~kg} \cdot \mathrm{ha}^{-1}$ aplikowanego rzędowo około $8 \mathrm{~cm}$ poniżej poziomu korzeni. W przypadku stosowania nawozów wolnodziałających punktowo pod korzeń, najwyższa dawka nawozu spowodowała zmniejszenie plonowania w porównaniu do obiektów z mniejszą dawką nawozów. Najlepsze efekty, z punktu widzenia wyrównania masy poszczególnych korzeni uzyskano w warunkach nawożenia konwencjonalnego. Najbardziej korzystną wartość współczynnika produktywności uzyskano w wariancie przy zastosowaniu nawozu wolnodziałającego na poziomie $400 \mathrm{~kg} \cdot \mathrm{ha}^{-1}$ aplikowanego punktowo, natomiast w przypadku aplikacji rzędowej, najbardziej korzystne efekty uzyskano przy dawce $600 \mathrm{~kg} \cdot \mathrm{ha}^{-1}$. Nawożenie selera nawozami wolno-działającymi pod korzeń może skutkować wytworzeniem plonu o większych różnicach masy jednostkowej korzeni w porównaniu z nawożeniem konwencjonalnym.
\end{abstract}

Słowa Kluczowe: seler korzeniowy, integrowana produkcja, nawozy wolnodziałające, efektywność nawożenia 